“Stranger/Medieval Things" Special Issue of Digital Philology

\title{
Putting the net back into the internet: the materiality of networks from a premodern perspective
}

Bettina Bildhauer, St Andrews

The energy consumption of the digital sector increased from an estimated $1.9 \%$ of the world energy consumption in 2013 to $3.7 \%$ in 2018 , with an exponential further growth predicted. ${ }^{1}$ The production, installing and running of the hardware of digital communication, such as computers, pipelines, server farms, smartphones and the Industrial Internet of Things, consume vast amounts of energy and raw materials while emitting greenhouse gasses. The carbon footprint of the internet alone was even in 2011 estimated to exceed that of air travel. ${ }^{2}$ The transition to digital technology is nevertheless often promoted as a solution to climate change. In the university sector, for instance, well-intentioned calls to replace in-person academic conferences with live streaming or to replace print publications with electronic downloads rarely even mention the energy consumption of such online practices. ${ }^{3}$ This perceived carbon-neutrality of electronic communication is evidently in the economic interests of the powerful information technology business. Another less obvious but more fundamental reason that hides the environmental cost of the material infrastructure of the internet seems to be a deeply engrained pattern of understanding the internet to be immaterial, the "dubious ontology" of digital things that Michelle Warren and Neil Weijer discuss in their article in this Special Issue. Try a random online image search for "internet", and you will find most images to be dominated by radiant light blue, ethereal lines and dots that indicate electricity and wireless connection, obscuring the material presence of pipelines 
and servers. This perception is hard to shift as it long predates the internet, with nets and networks considered immaterial in crucial ways throughout history.

This essay tackles this special issue's central question "what do medieval things have to tell us about connectivity and object-mediated communication?" head-on through setting our contemporary imaginations of the internet in the context of depictions of nets in medieval sources. These medieval conceptions of nets provide both a crucial historical precedent for our perception of the internet as an immaterial structure of knowledge, and a corrective to this perception by insisting that the distinction between material and immaterial is ultimately impossible to uphold.

While the terms "network," "internet" and "world wide web" are modern, they all rely on the notion of the net, which is among the oldest human technologies, dating back to at least the Mesolithic era. According to Sebastian Gießmann's pioneering cultural history of nets and networks, nets have long been important cultural technologies that were used to understand and visualize the workings of power, art and social obligation as well as later of artificial waterways, electricity grids, telephones and traffic. ${ }^{4}$ Gießmann sketches a history in which nets in ancient Mesopotamia, Egypt, India and Israel were seen primarily as powerful traps, but in ancient Greek and Roman culture and again since the Renaissance came to be associated instead predominantly with connectedness. ${ }^{5}$ Similarly, he observes that from early modernity onwards, nets and networks were typically imagined as fragile, transient and “immaterial" and no longer as materially sturdy. ${ }^{6}$

In this article, I will trace the idea of nets as non-material further back into premodernity than Gießmann, who largely omits the first thirteen centuries of the Christian Era from his history. The limited archeological evidence suggests that during the Middle Ages nets were used for carrying, hunting and fishing. ${ }^{7}$ Medieval literary and visual sources show hunting and fishing nets, but also decorative nets in hair and clothing. Rather than as 
connective and fragile, which are according to Gießmann the main perceived characteristics of modern networks, medieval sources typically portray nets as immaterial, or more precisely, as composed of material as well as of immaterial elements, of strings as well as of gaps in between; and as traps. They also already use nets as metaphors for structures of knowledge. Medieval cultural representations of nets emphasize the tension between material and immaterial components by exaggerating the invisibility of the nets from the outside, and the inescapability of the nets for those caught inside them.

In the following, I will show how medieval imaginations of nets as test cases for materiality both reveal some of the roots of our current perception of the internet as immaterial, and remind us of its simultaneous materiality. I will begin by clarifying the notions of materiality and "thingliness" that underlie contemporary and medieval imaginations of nets and networks. I will then sketch how medieval narrative texts both depict nets as immaterial traps, and complicate this perception by suspending the distinction between material and immaterial. The final section will show how medieval uses of nets as metaphors for structures of knowledge prefigure modern imaginations of the internet. I focus on medieval German literature, where I have conducted a survey of all texts digitized in the Middle High German Conceptual Database, but include some Arabic and English examples, as similar conceptions of nets are found throughout what we would now call Europe and the Middle East. ${ }^{8}$

\section{DEFINING MATERIAL THINGS AS VISIBLE AND TANGIBLE}

Materiality is an ambiguous concept even today, when our standard model of physics does not make a clear distinction between material particles and immaterial waves. Both popular understandings and philosophical definitions are currently based on a model of materiality 
and immateriality as a spectrum rather than as a binary. This assumption of a spectrum, however, is rarely stated explicitly and instead often has to be inferred from paradigmatic examples of material things, and from what no longer counts as a thing. Major criteria for perceived materiality appear to be tangibility and visibility, with material things also ideally being of the right size and weight to be transportable.

The importance of tangibility and portability is implied already in Martin Heidegger's highly influential phenomenological definition of things (equipment or Zeug) through their Zuhandenheit, that is, their "handiness" or "being ready-at-hand" for human use. ${ }^{9}$ The interaction with the human hand touching and moving the items is at the core of this definition. When Heidegger speaks of the characteristic human ability to survey a room full of equipment before handling it, he also implies visibility as an essential feature of a material thing. ${ }^{10}$ For all his sensitivity to things, underlying Heidegger's conception is still a clear distinction between a human subject seeing and handling things on the one hand, and the inanimate, inert material object being handled on the other. Playing on the etymology of "object" from the Latin for "to throw before", Lorraine Daston similarly describes things as "solid, obvious, sharply outlined [...] all too stable, all too real in the commonsensical meaning of 'hard to make go away' ". ${ }^{11}$ The examples of things that are most frequently mentioned in philosophical texts about things, such as jug, table, chair, pen and now also phone and computer, meet the criteria of visibility, tangibility and portability, whether this is made explicit or not. ${ }^{12}$

The same spectrum of materiality is evident in Vilém Flusser's update of Heidegger's phenomenological definition of thingliness for the information and network age. Flusser again defines a thing negatively and implicitly as graspable and solid, by distinguishing it from a "non-thing" (Unding), which is intangible. Unding is a term that literally means nonthing, but can also mean scandal, from the Old High German root of thing as a legal case. For 
Flusser the paradigmatic Unding is information, which lacks graspability even if it is contained in a physical computer. He implies that solidity and tangibility are what characterize things insofar as they are absent from non-things, which are "so 'soft' (software) that any attempt to grasp them with one's hands fails", and which create an "ever softer, foggier, ghostlier" and "spectral" environment that has superseded the material world in the contemporary period (“derartig 'weich’ (software), daß jeder Versuch, sie mit den Händen zu ergreifen, fehlschlägt”; “immer weicher, nebelhafter, gespenstischer," “spektral.”) ${ }^{13}$ The visibility of these hard tangible things is another important feature so central that it is taken for granted and simply implied in the contrast with information's ghostliness and spectrality. At the same time, Flusser's choice of terms ("ghostly", "fail", "spectral") betrays some of the anxieties about digital information's invisibility and lack of tangibility that are now widespread in fears of the internet entrapping vulnerable young people.

The binary of agential human subject and inert solid object that underlies these modern concepts of material things, and the distrust of entities that do not fit into these categories, was not yet quite as engrained before the Enlightenment. Medieval cultures and literatures were particularly interested in the overlaps and blurred areas between the material and the immaterial. Materiality's relation to transcendence had central Christian theological significance in the doctrines of the creation (the material world being created ex nihilo), the incarnation (the word becoming flesh, God becoming human in Christ) and to some extent transubstantiation (the material Eucharistic host becoming Christ). ${ }^{14}$ Late medieval European philosophy and theology, though on the surface quite Cartesian in its theoretical Aristotelean distinction between matter and form and between humans and the rest of creation, saw matter as highly creative, and ultimately failed to make a sharp distinction between life and inanimate matter, and human and non-human. ${ }^{15}$ Medieval European literature loved to explore the tension between real events in the material world and their translation into the 
world of language, which is often perceived as abstract and immaterial in its chief function as a code. As Ludger Lieb has argued, medieval narratives in general understood themselves as story matter in contrast to form in the Aristotelian sense: not matter as an unformed plot that could be adapted into various forms, but as in itself generative of a number of actualizations, "a powerful configuration of a finite amount of narrative possibilities". ${ }^{16}$ As we shall see in more detail below, visibility and tangibility are important criteria for the definition of material things in medieval texts, too, but nets never quite fit clearly into this category, and that seems to be the point.

\section{MEDIEVAL NETS AS INVISIBLE AND IMMATERIAL}

Nets are ideal for thinking through what a material thing is. Nets are usually uncontroversially considered to be material things because they are tangible, visible and transportable. As Hartmut Böhme has pointed out, however, nets are composed not only of strings but also of the gaps between strings. ${ }^{17}$ That which cannot be seen and touched, such as the air that circulates in the meshes of a net, is usually considered to be less material than the solid, easily visible fibres and knots. We are so focussed on the knots and lines that we do not even have a suitable term for the spaces in between, which are not really holes or gaps in the sense of accidental damage to the meshes, but integral to its functioning. ${ }^{18}$ The fact that hunting and fishing nets are at first inconspicuous to those whom they trap due to the gaps, but then physically hold them due to the strings, is an essential design feature without which they could not function. Ornamental nets that are used in clothing or on hair likewise depend for their effect on being visible in their beautiful materiality at the same times as allowing hair or fabric to shine through between the strings of pearls or gold. Premodern texts 
surprisingly often state explicitly that nets are transparent or hard to see, and sometimes exaggerate this into complete invisibility. This early perception of nets as invisible and therefore somehow less material can still or again be observed in our understanding of the internet as immaterial.

The Middle High German Arthurian romance Daniel of the Blossoming Valley (c. 1220) by a poet known only as Der Stricker (“the Knitter”), for instance, features an invisible net. The eponymous protagonist gets caught in it when he tries to enter a mountain kingdom:

Dâ stuont ein kleinez netze vor, daz was mit listen sô gemacht, ez waere tac oder naht, daz ez nieman ensach. ${ }^{19}$

In front of it [the mountain pass to the kingdom] stood a small net. It was artfully made so that day or night, nobody could see it.

Princess Sandinose, who has set the trap to guard her kingdom, explains later that this invisibility is due to magic.

Vulcan's net, well-known from ancient Greek and Roman myth, which the god forges from steel and silver in order to trap his wife Venus and her lover Mars, is also described as invisible, for example, in Heinrich of Veldeke's German adaptation of Virgil's Aeneid (c. 1170-90): "one could not see it, so small were the wires," ("daz manz kûme gesach,/ dô cleine wârn die drâte.” ${ }^{20}$ Its invisibility makes it possible for the other gods, alerted by Vulcan, to enjoy the spectacle of the naked Venus and to poke fun at the trapped lovers.

The eighth-century Arabic story collection Kalila and Dimna, based on the third- or fourth-century Sanskrit Panchatantra and widely read and translated throughout medieval 
Europe, relates a similar story of a net being at first invisible from the outside. In the narrative of the ring-dove, a crow "catches sight of" ("aperçut") a fowler spreading a net and seeds on the ground and continues to watch events unfold. ${ }^{21}$ A flock of ring-doves arrives who can "see the seeds but not the net" ("apercevant le grain mais non le filet") and gets caught up in it. ${ }^{22}$ After becoming trapped, however, the birds turn tables by together lifting the net up and carrying it to a forest, where they hope to become invisible to the fowler ("we will soon have hidden ourselves from his view," "nous aurons tôt fait de nous cacher à sa vue.”) ${ }^{23}$ (This is one of the few instances in medieval literature where the net arguably functions as connecting a group, as is one of its dominant associations today, albeit a flock of birds that already had some cohesion and is now forced together against their will.)

The mosquito net or conopeion around Holofernes' bed that allows Judith to kill him unseen is likewise often imagined as transparent in medieval versions of the story of Judith and Holofernes from the Hebrew Bible or Torah. The Old English Judith describes the net as invisible or at least transparent from the inside, though as opaque from without:

\author{
Thaer waes eallgylden \\ fleohnet faeger ymbe thaes folctogan \\ bed ahongen, thaet se bealofulla \\ mihte wlitan thurh, wigena baldor, \\ on aeghwylcne the daer inne com \\ haeldena bearna ond on hyne naenig \\ monna cynnes.
}

In that place an all-gold shimmering fly-net was hung around the general's cot, one through which the man of evil, lord of warriors, might look upon each man who came inside there no matter what kind of man, and upon him nobody of man's family. ${ }^{24}$ 
The mosquito net works as a two-way mirror out of which Holofernes, from his position in the bed, can see, but into which nobody can look upon him from the outside, probably because the lights are situated on the outside of the bed and reflect off the shimmering fabric rather than allowing glimpses into the dark space it covers. While a net is normally invisible to its prey from the outside, the spatial positions are reversed in this case: the mosquito net is highly visible from the outside but transparent from the inside. So the net remains invisible to its "prey," Holofernes, as usual, even if he is in this case already on the inside and about to be trapped without realizing it.

Not only the entrapping nets, but also decorative nets are at least in German-language medieval literature usually described as transparent or lacking visibility. A particularly lavish net attached to clothing features in Konrad of Würzburg's Trojan War (before 1287), for example:

durch daz rîlîche netze breit, daz löcherehte dûhte, des phellers varwe lûhte, diu sam ein gloie was getân. ${ }^{25}$

Through the precious wide net, which seemed to be full of holes, shone the silk fabric's iris-like color.

The fact that one can see the embroidered fabric through its holes is described as part of its attraction. The invisibility and transparency of such nets resurfaces in current perceptions of the internet as somehow floating above and divorced from its material infrastructure. 


\section{MEDIEVAL NETS AS ENTANGLING TRAPS}

The invisibility of medieval nets, which suggests a degree of immateriality, however, is only half the story. The nets mentioned so far are also typical of those in medieval German literature insofar as - with the exception of the decorative net - they are traps. They decide power struggles between humans, animals, gods and things: in the case of Daniel and Judith, between a local woman and a male intruder; in the case of Vulcan's net, between a divine husband and wife; in the case of the ring-doves, between a male human and a group of animals; and finally between the nets themselves as powerful things and the animals, humans and gods trapped in all of them. Such medieval stories about nets are stories about power, about hierarchies, about characters trapping other characters and thereby gaining the upper hand in a conflict. Many of these traps are intended to catch their victims in order to kill them, and the lethal danger for those inside the net is often mentioned. Though trapping has connotations of deviousness, and nets were historically shunned by medieval aristocratic hunters as not sporting enough, this is not necessarily the case in narratives, where our sympathies may well lie with the hunters.

The nets' entrapping nature in medieval texts is due not just to their invisibility to their prey from the outside, but also due to their tangible (and indeed entangling) materiality from the inside. Nets in medieval texts are characterized by a specific combination not only of reduced visibility, but also of exaggerated tangibility, as Christina Lechtermann has demonstrated for the German context. ${ }^{26}$ Premodern texts not only exaggerate a net's transparency or invisibility, but also its entangling tangibility. Nets interested many medieval writers precisely insofar as they stood at the limits of what still counted as a material thing. 
The net in Der Stricker's Daniel, for instance, is not just invisible, but also all too tangible. Here is how the protagonist gets entangled in it:

Daniel quam an die stat:

dô er in daz netze getrat,

owê! Wie sere er dô erschrac!

er viel nider unde lac

und was in kurzen stunden

sô sêre mite gebunden

daz er niht triuwete genesen.

er wolde vil gewis wesen

daz in der tîfel hebete.

mit der hant er strebete,

und wolde sich gesegnet hân.

daz muoste er under wegen lân.

er mochte einen vinger nicht geregen,

er mohte niht mê gewegen

wan diu ougen und die zungen,

dô er sô wart betwungen. ${ }^{27}$

Daniel came to this place. When he stepped into the net, oh no! What a shock he got! He fell down and was soon lying there so entangled that he didn't think he could escape. He thought the devil was holding him. He tried to lift his hand to bless himself, but he had to give up. He could not lift a finger, he could not move anything but his eyes and tongue, so overcome was he. 
This net's inescapable tangibility or rather tangliness is dramatized through Daniel's utter inability to move once he is caught inside. Sandinose confirms that the net can catch any animal and is so solid that it cannot be cut by any sword. She explains that a mermaid had given it to her father together with a matching magic ointment, which makes the net visible and which Sandinose and her parents have used. So her story returns the seemingly impossible - invisible but entangling - net to a more conventional thing: visible at least to some, with a definite material existence as a portable gift item. The same movement from an invisible but entangling entity to a portable item that is clearly a thing is repeated at the end of the narrative, when Sandinose uses the net to trap a dwarf who had kidnapped King Arthur and Parzival. Again the net's invisibility and the struggle of the trapped dwarf on the inside, thrashing about like a fish, are highlighted in impressive passages. The net is then again returned to functioning as a material, portable, giftable object when Sandinose and Daniel trade the net and the salve in return for the release of Arthur and Parzival.

The materiality of the ring-dove's net in the sense of its weight and consistency also becomes apparent in Kalila and Dimna as soon as the doves are caught in it and lift the net up together to the forest. The net then figures again in its material form as composed of string when a rat who lives in this forest and is friends with one of the ring-doves gnaws through the strings and frees the birds. Throughout this tale, the net veers between visibility and invisibility to the various characters involved, but in the end, its tangibility, portability and "gnawability" is emphasized. ${ }^{28}$

\section{MEDIEVAL NETS AS METAPHORS FOR STRUCTURES OF KNOWLEDGE}

Nets in medieval German narratives and beyond not only typically veer between material and immaterial, but they are also already metaphors for structures of knowledge, in a way that 
foreshadows and provides a root for the contemporary use of the term "network". Through its necessary inclusion of holes, according to Gießmann, a net is always on the way to becoming an immaterial "quasi-object" and therefore lends itself to becoming a metaphor for abstract structures of knowledge. ${ }^{29}$ As Anke Bernau explores in her contribution on the use of knots as a related metaphor for language in this special issue, we tend to think of metaphors as nonmaterial, but they nonetheless carry a trace of the material things to which abstract notions are compared. The distinction between language as immaterial code on the one hand, and the material concepts it describes plus its material carriers of voice or writing on the other, is of limited help here.

The vast majority of the nets mentioned in Middle High German narratives, in contrast to the ones discussed so far, are not actually part of the plot, but invoked only in metaphors or similes. They represent the snares of love or of death, but also surprisingly often the process of telling and interpreting stories as a structure of knowledge itself. The use of nets as metaphors for narrative can be seen in the wider context of the relatively wellknown tradition of associating texts and textiles in ancient Latin literature, which persisted into the Middle Ages. The specific case of nets rather than other textiles as metaphors for narratives, however, is also present in the Arabic Kalila and Dimna tradition. In some versions of Kalila and Dimna, the preamble ascribed to the Arabic translator from Sanskrit, Ibn Al-Moqafa, explicitly compares the casting of nets to the process of interpreting the narratives in the book:

Now a similar degree of sober reflection is essential for the reader of this book, if he would avoid the fate of the fisherman, who while trying to catch fish one day in a river, saw a shell at the bottom of the water and threw in his net to draw it out, but failed in his attempt and caught a fish instead. Although the fish was sufficiently large 
to serve him for food during that day, he did not think that it was worth keeping, so he jumped into the river to obtain the shell; and having brought it out, he found that it was empty, and regretted that by his own greed [he] had lost a certain benefit. $O$ n the following day he came back to the same river and throwing in his net, he took a small fish. At the same time he noticed another shell, but paid no attention to it, fearing that he should be disappointed as on the preceding day. $\mathrm{B} u$ t a fisherman happened to pass by and being attracted by the beauty of the shell, took it out of the water and found in it a pearl of great value. In the same manner as great a treasure awaits the endeavours of the person whose insight penetrates deeper than the reader who is merely satisfied with the superficial perusal of this book. ${ }^{30}$

This passage illustrates a model of situation-specific interpretation common to several global medieval narrative cycles that is net-like insofar as it necessarily includes gaps: as the net has gaps between its strings, so any interpretation has holes and cannot explain every aspect of the plot. The incompleteness of the interpretation is clear in the fact that although the narrator begins by comparing the first fisherman to the reader, they explicit interpret only one plot point of this multifaceted story in this figurative way: the fact that on the second day the first fisherman ignores a pearl-filled shell after one failed attempt to find a pearl. This is compared to "the superficial perusal of this book," which here probably means giving up after one failed attempt at reading or interpretation. The other elements of the tale that remain uninterpreted would not make sense if understood figuratively in this way, especially not the experience of the second fisherman, who only needs one catch to find a great treasure (if related to the reading process, this would contradict the idea that benefits do not come easily). That any interpretation is limited to its specific situation is also emphasized insofar as another part of the narrative, namely the catching and letting go of the small fish on the first day, is 
interpreted in a different context by the first fisherman himself, who regrets giving up "a certain benefit" through greed, or in other words concludes "better a bird in the hand than two in the bush." If this were related to the reading process, the message of being content with a minor benefit from reading would again contradict the stated recommendation not to be satisfied with an easy reward, but to peruse a text extensively.

This situation-specificity and incompleteness of each interpretation means that each explicit interpretation leaves enough elements of the plot unexplained for other readers to understand the stories differently. As much as a functioning net needs open meshes, the interpretation leaves gaps between individual lines and points of understanding. The gappiness is feature not only of the net, but also of the empty shell, which likewise combines immaterial emptiness with material surrounds. Both the net and the empty shell are here employed as visualisations of the holes in any interpretation, and the play of absence and presence in any process of turning concrete events into a verbal narrative, and turning a narrative back into concrete wise action, without it all adding up too neatly.

Nets are used as metaphors for narrative in German-language texts, too, for example, in Albrecht of Scharfenberg's Younger Titurel (Jüngerer Titurel, c. 1260-75), the Emperors' Chronicle (Kaiserchronik, 1147), and The Devil's Net (Des Tüfels Segi, c. 1400-1450). The entrapping net in Daniel of the Blossoming Valley has likewise been read as a metaphor for the captivating narrative. ${ }^{31}$ Mathias Meyer and Hartmut Bleumer both base this reading on the fact that Daniel re-narrates previous events to the dwarf when the latter is caught inside the net, in combination with the author's name ("the knitter"). Bleumer additionally relates the net's invisibility to the invisible text, which should be heard not seen in order to stimulate the imagination. He emphasizes the silence that precedes Daniel's retelling of the events to the dwarf as a necessary "free space," reminding recipients of how any spoken language needs both sound and silence to function. ${ }^{32}$ In this context, the net that combines material 
strings and gaps could be compared to the sounds and silences of spoken language, where soundwaves are considered to have more material presence than silences.

The comparison of narratives and nets can be seen in the context of broader shifts in medieval media technology from oral to written storytelling, from performance to private reading, and later from manuscript to print. These shifts are usually perceived as a gradual loss of tangibility and material presence first of the author, then of the performer, then of the handmade precious manuscript. In the medieval texts' interest in both invisibility and materiality of nets, we could then sense similar anxieties to those that Flusser expresses about the un-graspable, invisible nature of information. The plots of some of the medieval tales reassure their recipients that even an invisible net is in fact still a net, made from fibre or metal and crafted by human or divine hands. Daniel and the ring-dove's story in Kalila and Dimna (as well as the biblical version of Judith's story and Veldeke's story of Vulcan's net) end on the note that nets are graspable even if they initially seemed invisible, that they are not pure abstract ruses but have a material basis that needs to be removed, cut or chewed through before those trapped inside can get out. This trajectory could in light of the comparison made between nets and narrative be seen as an attempt at returning a degree of materiality to a narrative process that is understood to be increasingly immaterial. (This is irrespective of the fact that the process of story-telling is always considered immaterial to an extent insofar as language in its most important aspect as code is seen as immaterial, and insofar as the worlds that fiction conjures up are perceived as immaterial.) In this regard, these narratives show that a technology can be reformed from within by bringing back materiality into the nets that have slid over into metaphorical territory. As the lovers Venus and Mars, the struggling Daniel and dwarf, and the flock of ring-doves feel the net's materiality mostly from inside it, so the narratives themselves might try to reassure us about their own materiality from within the plot. 


\section{CONCLUSION}

Nets in the twenty-first century have come to the fore as a dominant metaphor for structures of knowledge, albeit in the form of "networks". "Network" is in itself a metaphor for complex structures that denies its link to material nets, insofar as networks are thought of as abstract. Networks stand in not for narratives specifically, but for virtually any field of knowledge, with the internet as the paradigmatic network. Though Gießmann identifies connectedness rather than trapping as the main modern connotation of the network, fears of getting trapped in the lure of the internet are rife. The tangibility of nets and the way in which they are by design hard to detect from the outside and hard to escape from the inside still (or again) structure the dominant conception of the hold of internet-based social media and games on vulnerable users.

I hope to have shown not only a premodern precedent to our perceptions of the internet as an invisible, immaterial but entangling trap, but also a premodern complication of that perception insofar as the binary distinction between immateriality and materiality is suspended in medieval depictions of nets. The acknowledgement of the material elements of nets in these texts could work as a corrective to our contemporary blind spot as regards the materiality of the internet. An answer to the opening question "what do medieval things have to tell us about connectivity and object-mediated communication?" is, then: medieval texts tell us that connectivity, even online connectivity, is always material; and that this materiality is always on the verge of invisibility.

\section{WORKS CITED}


Ahmed, Sara. Queer Phenomenology: Objects, Orientations, Others. Durham, NC: Duke University Press, 2006.

Berkhout, Carl T., and James F. Doubleday. “The net in Judith 46b-54a.” Neuphilologische Mitteilungen, 74: 4 (1973), 630-4.

Bildhauer, Bettina. Medieval Things: Materiality, Agency and Narratives of Objects in Medieval German Literature and beyond. Interventions: New Studies in Medieval Culture. Columbus: Ohio State University Press, 2020.

Bleumer, Hartmut, “Im Netz des Strickers: Immersion und Narration im Daniel von dem Blühenden Tal." In Wie gebannt: Ästhetische Verfahren der affektiven Bindung von Aufmerksamkeit, edited by Martin Baisch, Andreas Degen and Jana Ludtke, 179-210. Freiburg: Rombach, 2013.

Böhme, Hartmut. "Einführung: Netzwerke: Zur Theorie und Geschichte einer Konstruktion." In Netzwerke: Eine Kulturtechnik der Moderne, edited by Jürgen Barkhoff, Hartmut Böhme and Jeanne Riou, 17-36. Literatur - Kultur - Geschlecht Große Reihe 29. Cologne: Böhlau, 2004.

Bynum, Caroline Walker. Christian Materiality: An Essay on Religion in Late Medieval Europe. New York: Zone Books, 2011.

Calila e Dimna, ou Fables de Bidpai, en arabe. Edited by Silvestre de Sacy. Paris:

L’imprimerie Royale, 1816.

Cohen, Jeffrey Jerome. Stone: An Ecology of the Inhuman. Minneapolis: University of Minnesota Press, 2015.

Daston, Lorraine. "Introduction: The Coming into Being of Scientific Objects." in Biographies of Scientific Objects, ed. by Daston, 15-41. Chicago, IL: University of Chicago Press, 2000. 
Fables of Bidpa'I, The (the Indian Aesop): A New and Modern Translation. Translated by M. A. Mostafa. Cairo: Nile, 1948.

Ferreboeuf, Hugues. Lean ICT: Towards Digital Sobriety. Report of the Working Group directed by Hugues Ferreboeuffor the Think Tank The Shift Project, 2019.

Flusser, Vilém. “Das Unding I.” In Flusser, Dinge und Undinge: Phänomenologische Skizzen, 80-5. Munich: Hanser, 1993.

Gießmann, Sebastian. Die Verbundenheit der Dinge: Eine Kulturgeschichte der Netze und Netzwerke. Berlin: Kadmos, 2014 (2nd, virtually identical edition 2016).

Gombiner, Joel. "Carbon Footprinting the Internet.” Consilience: The Journal of Sustainable Development 5, no. 1, 2011, 119-124.

Heidegger, Martin. Sein und Zeit. Tübingen: Neomarius, 1949.

Heidegger, Martin. Being and Time. Translated by John Macquarie and Edward Robinson. London: SCM Press, 1962.

Heinrich von Veldeke. Eneasroman: Mittelhochdeutsch/Neuhochdeutsch. Edited by Ludwig Ettmüller, translated by Dieter Kartschoke. Stuttgart: Reclam, 2014.

Ibn al-Muqaffa, Abdallah. Le livre de Kalila et Dimna. Translated by André Miquel. Paris: Klincksieck, 1957.

“Judith.” In The Longman Anthology of Old English, Old Icelandic and Anglo-Norman Literatures. Edited and translated by Richard North, Joe Allard and Patricia Gillies, 401-19. Harlow: Pearson, 2011.

Kalila and Dimna or the Fables of Bidpai. Translated by Wyndham Knatchbull. Oxford: Baxter, 1819.

Konrad von Würzburg. Trojanerkrieg. Edited by Heinz Thoelen and Bianca Häberlein. Wissensliteratur im Mittelalter, 51. Wiesbaden: Reichert, 2015. 
Lechtermann, Christina. "Vulkans Waffe." In Perspicuitas: Internet-Periodicum für mediävistische Sprach-, Literatur- und Kulturwissenschaft, Netzstrukturen: Zur Kulturgeschichte sprachlicher, visueller und technischer Netze, http://www.perspicuitas.uni-essen.de/sammelbd/netzstrukt/lechtermann_vulkan.pdf, uploaded 24 July 2006; 14 pp., no pagination.

Lieb, Ludger. "Die Potenz des Stoffes: Eine kleine Metaphysik des Wiedererzählens.” In Zeitschrift für deutsche Philologie, Sonderheft zum Band 124: Retextualisierungen in der mittelalterlichen Literatur, 2005, 365-79.

Meyer, Matthias. Die Verfügbarkeit der Fiktion: Interpretationen und poetologische Untersuchungen zum Artusroman und zur aventiurehaften Dietrichepik des 13. Jahrhunderts, Germanisch-Romanische Monatsschrift Beiheft, 12. Heidelberg: Winter, 1994.

Olsen, Ole Mikal. "Medieval fishing tackle from Bergen.” In The Bryggen Papers 5: Medieval Fishing Tackle from Bergen and Borgund. Edited by Ingvild Øye, 11-106. Bergen: Fagbokforlaget, 2004.

Parncutt, Richard, and Annemarie Seither-Preisler. "Live streaming at international academic conferences: Ethical considerations." Elementa: Science of the Anthropocene 7 no. 55 , 2019. https://doi.org/10.1525/elementa.393

Robertson, Kellie. Nature Speaks: Medieval Literature and Aristotelian Philosophy. Philadephia: University of Pennsylvania Press, 2017.

Schjølberg, E. "Cordage and Similar Products from Bryggen in Bergen.” In The Bryggen Papers: Supplementary Series 3, 69-138. Bergen: Universitetsforlaget, 1988.

Schmitz, Barbara. "Holofernes's Canopy in the Septuagint." In The Sword of Judith: Judith Studies across the Disciplines, edited by Kevin R. Brine, Elena Ciletti and Henrike 
Lähnemann. Cambridge: Open Book Publishers, 2010.

http://books.openedition.org/obp/990?lang=en.

Steel, Karl. "Medieval." In The Cambridge Companion to Literature and the Posthuman, edited by Bruce Clarke and Manuela Rossini, 3-15. Cambridge: Cambridge University Press, 2017.

Stricker, Der. Daniel von dem blühenden Tal, edited by Michael Resler, Altdeutsche Textbibiliothek 92. Tübingen: Niemeyer. $2^{\text {nd }}$ edition, 1995.

\section{NOTES}

${ }^{1}$ Ferreboeuf, Lean ICT, p. 16.

${ }^{2}$ Gombiner, "Carbon Footprinting the Internet."

${ }^{3}$ Parncutt and Seither-Preisler, "Live Streaming."

${ }^{4}$ Gießmann, Verbundenheit der Dinge.

${ }^{5}$ Gießmann, Verbundenheit der Dinge, pp. 17-115, esp. 114.

${ }^{6}$ Gießmann, Verbundenheit der Dinge, pp. 101-15, esp. p 112.

${ }^{7}$ Olsen, "Medieval Fishing Tackle"; Schjølberg, "Cordage and Similar Products."

${ }^{8}$ An earlier version of this article with further examples is found in Bildhauer, Medieval

Things, pp. 59-92. Thank you to The Ohio State University Press for permission to reuse this material. All translations are mine, except where a published translation is cited.

${ }^{9}$ Heidegger, Being and Time, p. 98; Heidegger, Sein und Zeit, p. 69.

${ }^{10}$ Heidegger, Being and Time, pp. 97-8, Heidegger, Sein und Zeit, p. 68.

${ }^{11}$ Daston, "Introduction," p. 2.

${ }^{12}$ On the ubiquity of tables in philosophy, see Ahmed, Queer Phenomenology, esp. pp. 3-4.

${ }^{13}$ Flusser, "Das Unding, I," pp. 81 and 82. 
${ }^{14}$ Cf. Bynum, Christian Materiality, pp. 34-5.

${ }^{15}$ E.g., Bynum, Christian Materiality; Cohen, Stone, pp. 195-52; Robertson, Nature Speaks; Steel, "Medieval".

${ }^{16}$ Lieb, “Potenz des Stoffes,” esp. pp. 369-70.

${ }^{17}$ Böhme, "Einführung."

${ }^{18}$ Böhme, "Einführung," p. 22.

${ }^{19}$ Stricker, Daniel, 11. 4128-31.

${ }^{20}$ Heinrich, Eneasroman, 11. 5638-9.

${ }^{21}$ Ibn al-Muqaffa, Kalila et Dimna, 133.

${ }^{22}$ Ibn Al-Muqaffa, Kalila et Dimna, 134.

${ }^{23}$ Ibn Al-Muqaffa, Kalila et Dimna, 134.

24 “Judith,” pp. 404-5, 11. 46-54, including translation.

${ }^{25}$ Konrad, Trojanerkrieg, 11. 32560-3.

${ }^{26}$ Lechtermann, "Vulkans Waffe," Bildhauer, Medieval Things.

${ }^{27}$ Stricker, Daniel, 11. 4145-60.

${ }^{28}$ Even a decorative net's effect depends not only on the fabric visible through it, but also on the contrast with its precious strings. In Konrad's case, the narrator mentions not only the gaps through which the fabric is visible, but also the precious material and artful craftedness of the net, which is made "carefully from little pearls" ("von berlîn kleine/ mit hôhem flîze"), Konrad, Trojanerkrieg, 11. 35258-9.

${ }^{29}$ Gießmann, Verbundenheit der Dinge, p. 8.

${ }^{30}$ Fables of Bidpa' $i$, trans. Mostafa 46. This passage is not found in Miquel's French translation, which is usually considered to be the most accurate Western one (Ibn al-Muqaffa, Kalila et Dimna), so I quote instead from Mostafa's English translation (Fables of Bidpa'i, 46), which does not give its Arabic source. The letters in italics are corrections of obvious 
spelling mistakes: "On" for "on," "he" for "be," "But" for "Bnt." The passage is also found in Wyndham Knatchbull's translation (Kalila and Dimna, trans. Knatchbull, pp. 62-3) of the Arabic edition Calila e Dimna by Silvestre de Sacy.

${ }^{31}$ Meyer, Verfügbarkeit der Fiktion, pp. 55-6; Bleumer, “Im Netz des Strickers,” pp. 203-5. ${ }^{32}$ Bleumer, "Im Netz des Strickers," pp. 203-5. 